\title{
The Impact of Current EU Climate and Energy Policies on the Economy of Poland
}

\author{
Ireneusz Miciuła*, Pawel Stępień \\ Institute of Finance, Faculty of Economics and Management, University of Szczecin, \\ Szczecin, Poland
}

Received: 13 March 2018

Accepted: 6 May 2018

\begin{abstract}
This is an analysis of the climate and energy policy of the European Union and its impact on the economic situation of Poland. The aim of the article is to show the direct impact of modern European Union policy in this area on the economic situation of states, in particular Central Europe. Simultaneously, we develop recommendations for the Polish and the European Union in terms of future climate and energy policy through the analysis of empirical data and practices followed by the European Union countries. The basis of the presented considerations and recommendations is a literature review of the studied subject and a statistical analysis of empirical data, which indicate the financial effectiveness of different energy sources and processes taking place in the world under the discussed issues.
\end{abstract}

Keywords: renewable energy sources, EU energy and climate policy, financial effectiveness

\section{Introduction}

The current energy policy of Poland aims towards improving energy efficiency, increasing energy security, and limiting the impact of the power industry on the environment. These goals stem from the European Union's energy policy, which calls for establishing a competitive and efficient energy market that would provide prosperity and improve Europe's competitiveness in the global market. To date, national and EU legislators have focused on introducing market mechanisms in the trade of electricity. Markets in the EU Member States were liberalised, which allowed end users to order electricity from individual power- generating entities of their own choosing. However, even though power generation and supply services are provided based on the principles of free-market competition, transmission and distribution networks are still subject to a natural monopoly. This competitionmonopoly hybrid emphasises the importance of regulation mechanisms, which should aim to eliminate monopoly rents. In recent decades, the development of renewable energy sources has become one of the major goals of the EU Member States' energy policy.

Resulting from this policy was the establishment of a mandatory share of renewable energy sources in the total national energy consumption. Undoubtedly, sustainable development of the power industry based on diversification of raw fuel sources, including renewable energy sources, is environmentally, economically, and socially beneficial (Table 1).

*e-mail: irekmic@wneiz.pl 
Table 1. Benefits of using renewable energy sources.

\begin{tabular}{|c|c|c|}
\hline Item & Environmental benefits & Social and economic benefits \\
\hline 1. & Reduced $\mathrm{CO}_{2}$ emissions & $\begin{array}{c}\text { Preserving non-renewable fossil fuel resources, use of renewable } \\
\text { energy sources to their full potential }\end{array}$ \\
\hline 2. & $\begin{array}{c}\text { Reduced emissions of pollutants, including } \mathrm{SO}_{2}, \mathrm{NO}_{x}, \\
\text { organic substances, heavy metals, } \\
\text { etc. to the environment }\end{array}$ & $\begin{array}{c}\text { Implementing international commitments applicable to emissions } \\
\text { of harmful substances to the atmosphere, participation in financial } \\
\text { benefits (trade in emission allowances or renewables, e.g., biomass) }\end{array}$ \\
\hline 3. & $\begin{array}{c}\text { Limiting environmental degradation caused by } \\
\text { exploitation fossil fuels and depositing biomass waste } \\
\text { in the environment }\end{array}$ & $\begin{array}{c}\text { Growth stimulation in numerous branches of the economy, in- } \\
\text { cluding advanced technology industries; supporting local labour } \\
\text { markets }\end{array}$ \\
\hline 4. & $\begin{array}{c}\text { Limited environmental degradation resulting from } \\
\text { unorganised bio-decomposition of deposited biomass }\end{array}$ & Improved quality of life and increased energy security of the \\
country
\end{tabular}

Source: own research based on [14, 26, 32]

However, what is also important is the financial viability of changes related to raw fuels, which affect entire economies, and the possible pace of such changes in the context of environmental, socio-economic, and technological constraints. Moreover, the EU climate policy enforces replacement of energy derived from coal with more environmentally friendly energy [10, 13]. This strategy is not beneficial for countries such as Poland, where coal is currently the primary source of energy. The production of electricity from coal in November 2016 accounted for $79.2 \%$ of total electricity production [23]. This is clearly visible in the context of rapid changes, i.e., those to be made by 2030. These changes are neither reasonably justified nor financially viable as the substitute solutions offered will not be profitable without national or EU subvention or funding, as you can see in Fig. 1.

These trends confirmed prices from 2016. Unit cost of electricity generation (in PLN per MWh): gas and steam mono-fuel - 276, carbon (combustion of air) 279 , atomic - 419, wind - 522, and photovoltaic - 1217 [28]. Furthermore, the changes have caused unsettling occurrences and disturbances in the energy markets, affecting prices in the entire economy. An exemplary problem resulting from EU strategies that were not carefully thought out are the prices of $\mathrm{CO}_{2}$ emission allowances. Since early 2014, they have increased by over 40 per cent to about EUR 7 per ton [23]. The increased demand is related to the recent EU climate

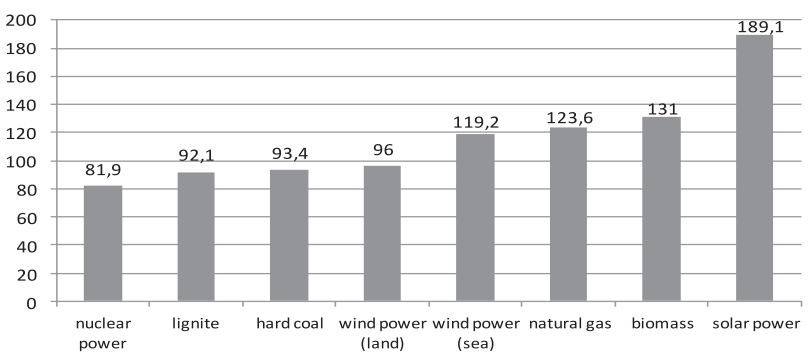

Fig. 1. Costs of electricity production (in EUR per MWh, prices from 2012). Source: [3] policy decisions, e.g., the $40 \%$ goal for reduction of $\mathrm{CO}_{2}$ emissions by the year 2030 , as well as the expected withdrawal of some of the allowances from the market [31].

Given the fact that $55 \%$ of raw fuels are imported to EU Member States, the EU strategy should also focus on finding substitutes to these fuels, or attempt to diversify their sources, which in turn will affect prices of raw fuels [1]. Yet the strategy focuses solely on the "energy mix," i.e., the division of energy production and consumption based on media or methods of production in individual economies with the goal of reducing the production of carbon dioxide [21]. What is not mentioned is the fact that this goal may also be reached by investing in innovative (clean) coal technologies. It is of paramount importance to the economies where the share of coal in the energy mix exceeds $50 \%$ - e.g., Poland, the Czech Republic, Greece, Bulgaria, and, in the near future, Germany. Furthermore the government report "Optimum Energy Mix Model for Poland by the Year 2060" states that the Polish power industry will be based on coal for almost another 40 years [30]. Therefore, the EU strategy should take into consideration the capabilities and specific conditions in different economies instead of generalising and adapting the trends to the major decision makers in the EU, who change the set goals while they are being implemented.

\section{Materials and Methods}

The article contains scientific research based on a literature review of the studied subject and statistical analysis of national data (Central Statistical Office of Poland) and international data agencies (Statistical Review of World Energy, International Energy Agency, Key World Energy Statistics, Global Energy Statistical Yearbook). Within the empirical data, analysis was carried out from 1988 to 2016 with an assessment of the forecasts to 2030 for energy sources in Poland. Additionally, as part of research methods we used 


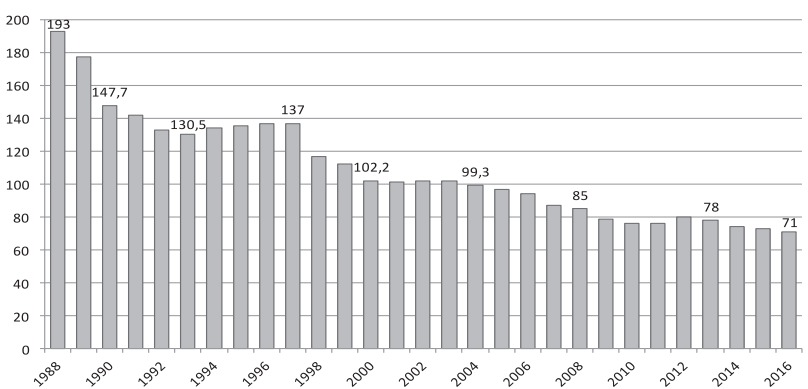

Fig. 2. Production of hard coal in Poland in 1988-2016 (in millions of tons). Source: own research based on $[6,11]$

assessment of financial efficiency and analysis of global institutions regarding the possibility of using various specific energy sources in specific areas of geography. As part of the financial and political analysis of the contemporary international situation on the energy market we discussed the impact of climate and energy EU policy on the economic situation of the countries of Central Europe on the basis of the results of research conducted as an attempt to develop such important recommendations for current activities of the Polish energy policy.

\section{Results and Discussion}

Arguments in favour of measured and effective changes include forecasts predicting an increased demand for energy and the limitations that prevent renewable energy sources from satisfying more than $15 \%$ of the total demand for energy in the EU countries in the long term [27]. At the same time, numerous raw fuels are becoming more and more environmentally friendly due to the use of modern technologies. A good example is shale gas. Also worth mentioning is the fact that the majority of EU countries, with the exception of Poland, have depleted their hard coal deposits. Most of those countries continue to use their lignite deposits despite EU policies, lower calorific value of this fuel, and higher $\mathrm{CO}_{2}$ emissions. Paradoxically, Germany is the

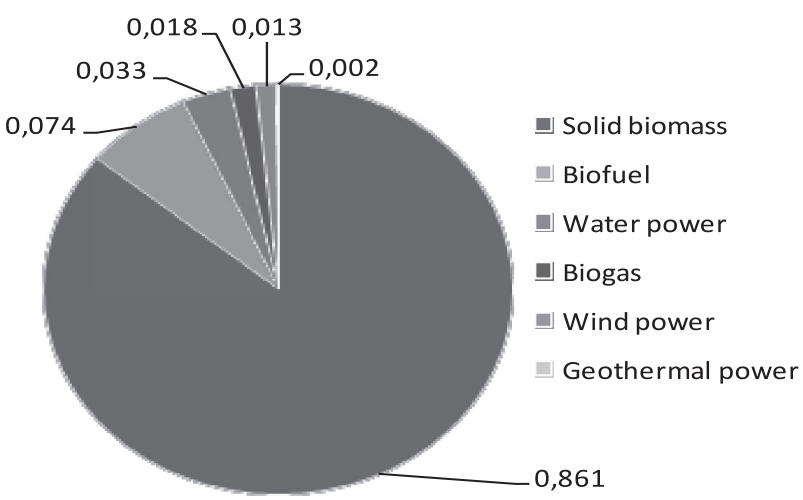

Fig. 4. Renewable energy sources in Poland in 2015 (\%). Source: own research based on [5]

leader in this field, at the same time being responsible for the directions of the current EU climate policy [13]. Meanwhile in Poland, the coal mining industry is going through a crisis, mostly because of ineffective internal management but also due to the implementation of EU policies. This is clearly visible in the charts below, which illustrate a considerable decrease in hard coal production in Poland (Fig. 2). As a result of this decrease, Poland has had to import coal in the last few years (Fig. 3).

Thus, the EU should support the idea of countries using their own resources together with innovative coal technologies, which would result in $\mathrm{CO}_{2}$ emission levels similar to those associated with the majority of renewable energy sources [20]. The situation regarding energy production in Poland is similar to that in other Central European countries, i.e., they do not have large deposits of raw fuels other than coal. If the current EU strategy is continued, these countries will be forced to import considerable amounts of raw fuels - especially oil and its derivatives as well as natural gas, due to shortages of their own resources.

In recent years, the volume of electricity produced in co-firing plants using coal and biomass has increased. Biomass is currently one of the major sources of renewable energy in EU countries [11]. Because of the need to meet the EU goals as well as climate and

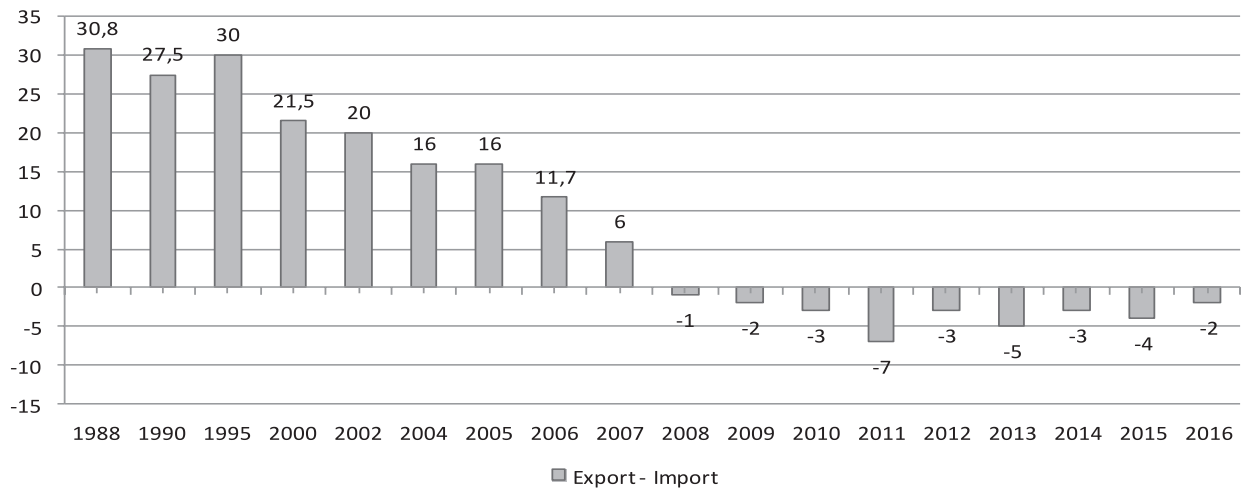

Fig. 3. Comparison of export and import of hard coal in 1988-2016 (in millions of tons). Source: own research based on [6] 


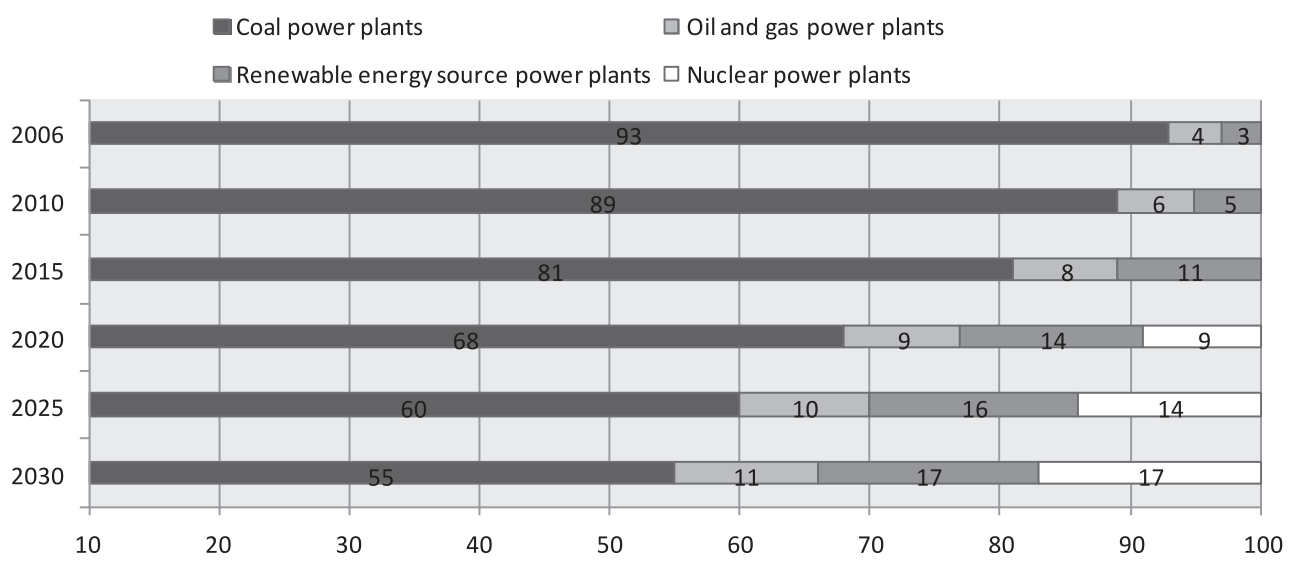

Fig. 5. Share of various fuels in the production of electricity in Poland in 2006, 2010, 2015, and by 2030 (\%). Source: own research based on $[2,7,30]$

environmental requirements, it is estimated that in the upcoming decades the use of biomass in energy production will increase rapidly throughout Europe [29]. Again, biomass is one of the major sources of renewable energy. In 2015, solid biomass comprised $86.1 \%$ of renewable energy sources in Poland and it was, and still is, mainly derived from wood (Fig. 4). This trend can be observed in most EU countries and stems from the availability of subsidies, binding legislation related to percentage-share of renewables, and limitations in the development of other renewables.

In 2015, biomass was used to produce $6305 \mathrm{GWh}$ of electricity, including $5593 \mathrm{GWh}$ generated using co-firing technology. Biomass is consumed by farms for heating and by professional power generation companies, mostly in co-firing with coal. Because of limited resources and its burning properties, biomass should mostly be used at a local level in dispersed power generation, as its transport has side effects in the form of additional $\mathrm{CO}_{2}$ emissions. Forecasts suggest that the demand for power will continue to increase until 2030 [24]. Thus limiting the share of fossil fuels in the Polish energy mix will result in economic problems, especially in light of the difficulties in producing electricity from renewable energy sources and despite the construction of two nuclear power plants, one of which will be ready by 2030 . The Polish energy mix will certainly differ from what is presented in the forecast by the Ministry of the Economy shown below, and the share of coal in the year 2030 will surely be much higher than estimated in the report (Fig. 5).

Before making the switch to renewable energy sources, the extent of such a change needs to be established for individual countries or regions. The tables below show various types of renewable energy sources and list their advantages and disadvantages as well as conditions and application opportunities specific to Poland (Table 2).

Due to limitations and lack of possibilities for rapid renewable energy development, it is necessary to use intermediate methods that will ensure stable and sustainable development of EU Member States. The fact that renewable energy sources currently meet about $9.5 \%$ of global demand for energy confirms

Table 2. Advantages and disadvantages of renewable energy sources.

\begin{tabular}{|c|c|c|}
\hline Energy source type & Advantages & Disadvantages \\
\hline Hydropower & $\begin{array}{c}\text { Very few problems related to maintenance } \\
\text { and operation of power plants }\end{array}$ & $\begin{array}{c}\text { Dependence on precipitation, need to devote large areas for } \\
\text { reservoirs and to resettle people, destruction of natural habitats } \\
\text { of plants and animals; local climate changes }\end{array}$ \\
\hline Biomass & $\begin{array}{c}\text { Large potential in some regions, } \\
\text { utilisation of waste and wastewater, land use, } \\
\text { and cultivation }\end{array}$ & $\begin{array}{c}\text { Need to cultivate plants, high costs, large area needed, burning } \\
\text { - production of hazardous substances }\end{array}$ \\
\hline Wind power & Clean renewable energy source & $\begin{array}{c}\text { High construction and maintenance costs; wind turbines take } \\
\text { space which could be used for farming }\end{array}$ \\
\hline Geothermal power & Clean energy source & $\begin{array}{c}\text { Expensive systems, difficult maintenance of equipment; the } \\
\text { required types of rock are found in few places around the world }\end{array}$ \\
\hline Solar power & $\begin{array}{c}\text { Solar panels do not require maintenance and } \\
\text { are reliable }\end{array}$ & Photovoltaic cells are constructed using toxic substances \\
\hline
\end{tabular}

Source: own research based on $[13,14,19]$ 
Table 3. Possibilities of using renewable energy sources in Poland.

\begin{tabular}{|c|c|}
\hline Type of energy & Reasons for limited applicability in Poland \\
\hline Wind power & $\begin{array}{l}\text { The average wind speed exceeds } 4 \mathrm{~m} / \mathrm{s} \text { only in some regions of the country; this is the minimum start-up value } \\
\text { for most wind power plants }\end{array}$ \\
\hline Solar power & $\begin{array}{l}\text { Out of } 8760 \text { hours of the year, insolation is available in Poland for } 1390 \text { to } 1900 \text { hours; in most regions } \\
\text { the average annual insolation is } 1600 \text { hours, which translates into } 30-40 \% \text { of a day; total solar radiation in Poland } \\
\text { (the aggregate of direct and scattered radiation) reaches a maximum value of } 1 \mathrm{~kW} / \mathrm{m}^{2} \text { in optimum conditions } \\
\text { (midday, no cloud cover, clear sky) }\end{array}$ \\
\hline $\begin{array}{l}\text { Geothermal } \\
\text { power }\end{array}$ & $\begin{array}{l}\text { It is possible to obtain } 4 \text { million tons of theoretical standard fuel from geothermal sources per year in Poland; } \\
\text { the majority of waters have a temperature of } 80^{\circ} \mathrm{C} \text {, which limits their applications in heat production }\end{array}$ \\
\hline Tidal power & This type of power plant cannot be used in Poland as there are no major high and low tides \\
\hline
\end{tabular}

Source: own research based on $[2,7,25]$

that their application in some parts of the world is limited, what you can see in table number 3 , and that the goals set by the EU for their share in the energy mix are unrealistic [27]. An additional argument to be considered is the cost-effectiveness of various solutions at a given stage of development of individual countries, including Poland.

At the same time, there are numerous arguments in favour of using coal and gas. These include the existence of innovative coal-burning technologies with improved energy efficiency, allowing for the use of resource deposits that could not be reached with conventional methods. Additionally, new technologies are more environmentally friendly and allow for limiting emissions of $\mathrm{CO}_{2}$ and other pollutants. For example, the oil refinery in Gdańsk is one of the most energy-efficient plants of its kind in Europe. Thus, Poland should continue to develop innovative and clean coal technologies. The table below shows the financial difference related to using such technologies vs. conventional methods, amounting to about $\$ 750$ US and yielding a considerable reduction of $\mathrm{CO}_{2}$ emissions, which is comparable to the level of emissions from some renewable energy sources (Table 4).

Commitments resulting from the EU climate framework related to producing power from renewable energy sources and construction of new production sources, including nuclear power plants, will have a considerable impact on Poland's economic situation as they require investment in distribution systems.

Traditional mining technologies used in coal exploitation allow for extracting only several percent of the deposits. In the case of the thermal process, the energy stored in coal is used more efficiently. In addition, this method allows for using the deposits that previously could not be reached using conventional methods. This technology is more environmentally friendly than traditional mining and converting coal into energy or raw fuel. The latest advancements in drilling technology, e.g., directional drilling, allow for conducting fully controlled coal thermal processes underground. In Poland, with its favourable geological conditions, coal gasification is a viable solution as the country has considerable hard coal and lignite deposits. Underground gasification allows for obtaining gas with a calorific values reaching up to $14 \mathrm{MJ} / \mathrm{m}^{3}$ [22]. Also, mining companies are making technological and economic efforts to increase the use of extracted and captured methane. In 2010, about 132 million $\mathrm{m}^{3}$ of methane was captured, $70 \%$ of which was used for energy generation. In the same year, the captured methane was used to produce 204,000 MWh of electricity and 771,000 GJ of heat [18]. A major cost-related benefit of using methane captured from ventilation air is avoiding fees for methane emissions, while at the same time receiving additional emission reduction units which are equivalent to $\mathrm{CO}_{2}$ emission allowances. These allowances, in turn, may be sold by the mines in the market. In 2012, JSW (a Polish mining company) generated profit of PLN 2 million by selling its $\mathrm{CO}_{2}$ emission allowances. This was possible due to limiting methane emissions by draining the gas from mines and then making use of it via burning. At the same time, if the EU continues its restrictive climate policy, implementation of CCS technologies will be a make-or-break solution for Polish mining and power industries in the future. This is because the policy states that by 2030 the number of $\mathrm{CO}_{2}$ allowances will

Table 4. Difference in costs for a $500 \mathrm{MW}$ power plant.

\begin{tabular}{|c|c|c|}
\hline & Coal & IGCC technology, capturing $90 \% \mathrm{CO}_{2}$ \\
\hline Power plant cost in $\$ / \mathrm{kWe}$ & $\$ 1913$ & $\$ 2719$ \\
\hline $\mathrm{CO}_{2}$ emissions $\mathrm{g} / \mathrm{kWe}-\mathrm{h}$ & 830 & 102 \\
\hline
\end{tabular}

Source: [9] 
have been decreased, thus their price will rise. On the example of the Bełchatów power plant, the cost of using $\mathrm{CCS}$, i.e., capturing and transporting $\mathrm{CO}_{2}$, is about PLN 100 for each MWh, plus the cost of $\mathrm{CO}_{2}$ storage, which is estimated at about PLN 5 per ton of $\mathrm{CO}_{2}$ [12].

Another solution is using synthesis gas (DME), which may be produced from a mixture of coal, natural gas, and biomass. The synthesis gas produced may be used as an energy source, but also as a raw material for chemical industry and as fuel for cars [15]. These arguments support stable unrushed changes in the power industry. As mentioned before, the Polish oil refinery in Gdańsk is one of the most energy-efficient plants of its kind in Europe. Therefore, focus should be placed on developing clean coal-burning technologies [8]. The undeniable evidence for this thesis is data showing the intensive growth of coal mining in the world. From the beginning of the 21st century until 2012, global coal production growth was practically $100 \%$ (from 3641 million tons to 7166 million tons in 2012). From 2013 to 2017, worldwide coal production stabilized at around 7,500 million tons, [17] which is due to the limited access to its resources. It is worth noting that three countries (USA, China, and India) are responsible for mining about $65 \%$ of coal in the world. In Europe, due to the limited resources of coal, there is a drop in output, including in Poland, which has the largest coal deposits in the European Union.

The legitimacy of using coal as a source of energy is confirmed by the fact that currently about $52 \%$ of the world's energy is obtained using its deposits and German policy, which, having brown coal deposits, increases its extraction and becomes a global leader [17], contrary to the theory of its own policy. Under the Industrial Emissions Directive (IED) of 8 November 2010, EU Member States are obliged to limit their carbon dioxide emissions [10]. The purpose of this directive is to introduce stricter regulations regarding industrial emissions and set more stringent conditions for issuing additional $\mathrm{CO}_{2}$ emission permits. In Poland, whose economy is based on coal, these changes will have a considerable impact on the energy source structure. Although environmentally friendly energy sources should be used for the benefit of the sustainable development concept, alternative solutions are required in locations where their application is limited. Additionally, changes that are imposed and too rapid may have a negative impact on economic and social growth. In this context, it is worth noting that advancements in technology allow coal-burning plants to meet very rigorous requirements regarding permissible emission levels. No coal-burning plant will be able to function without effective desulphurisation, denitrification (SCR), and particulate filtering systems. In each of those cases, considerable investments are required. According to calculations of the Polish Chamber of Chemical Industry, investment costs for a large chemical plant amount to about $€ 120$ million per year [23]. However, investing in renewable energy sources requires even greater expenditure and it may not be economically viable without financial support from the EU. Therefore, the directive also includes regulations allowing for extending the operation of power and heat plants pursuant to previous principles, provided that their output does not exceed $200 \mathrm{MW}$. With the additional use of integrated permits obtained before 27 November 2002, it is possible to deliver more than $50 \%$ of heat generated by these plants to the heating networks. Depending on the methods and tools used in its implementation, the above solution allows for a more neutral adaptation to the new requirements. Also, the current state of affairs in the EU suggests that strict climatic policies will be abandoned in favour of energy security and competitiveness of economy.

All EU Member States strive to reduce $\mathrm{CO}_{2}$ emissions, but they differ in their opinions on how to reach this goal. What is important in this context is the limitations and feasibility of the EU plans in individual countries and the economic effects that may occur as a result of unfavourable processes enforced by means available to the EU, e.g., financial penalties, and the $\mathrm{CO}_{2}$ emission permit market. These effects will most profoundly affect developing countries and will result in creating natural monopolies among developed countries [4]. The impact of such activities on the functioning of economic entities will be immense. For this reason, it is crucial to take actions resulting in sustainable development of all EU countries and providing energy security in a way that is based on rational and effective use of raw fuels [16]. What follows is that the share of coal and gas will have to be greater than predicted in the forecasts related to the EU strategy. This, in turn, means that carbon dioxide emissions will have to be curbed, which is possible through the development of modern technologies. Moreover, EU climate policy should take into account the specific energy mixes of individual countries instead of imposing a single criterion on all of them. In its plans, the European Commission should consider the characteristics of individual countries and their development strategies and adapt deadlines to each country individually. Changes in the methods used to produce energy and the move toward sustainable development as specified in the EU assumptions require time. Additionally, arguments such as economic viability of production, the ability to use products developed for other purposes, and technical development that meets the requirements of environment protection support stable and measured changes leading to sustainable development around the world.

\section{Conclusions}

Poland became part of the International Energy Agency (IEA) in 2008 [17] after substantial work related to amending and creating legal regulations designed to maintain required reserves and limit demand for power. This increased security in relation to liquid 
fuel availability also allowed Poland to participate in the works of one of the most important international organisations in the field of power generation and contribute to shaping broadly defined energy security (energy efficiency, use of renewable energy sources, prevention of negative effects of disturbances in the supply of natural gas, or clean coal technologies). On the other hand, one must not overlook the overall EU climate policy, which became a doctrine that is resistant to sound and, first of all, financial arguments. This policy has three major driving forces: particular interests, ideology, and political needs of the EU leaders (i.e., Germany and France, which are interested in selling renewable energy and nuclear technologies, respectively). Poland is forced to pay the highest fees for natural gas despite having some of the largest raw fuel deposits in the EU and being one of the few European countries that could be independent in terms of energy production if only the colonial burden imposed by the West and fuel dependence from the East could be removed. The present situation is also the result of the inefficiency of the Polish authorities and lack of strategic investment projects. For example, the current condition of Poland's power network may soon limit the country's ability to pursue an efficient energy policy. Moreover, the prospects for expanding or modernising the existing network are limited in the present legal landscape. Even though developing the power network is a public goal and the energy law obliges transmission and distribution network operators to provide the required level and reliability of supplies, the Polish legal system does not provide adequate tools to meet these requirements. In some regards, the development of the Polish power industry is blocked by the lack of legal solutions required, while in others, overregulation is the problem [7]. This is why the authors' recommendations for Poland's 2030 energy policy include:

1) Improvement in energy efficiency: A consistent decrease in energy consumption of the Polish economy to level UE-15 through modernisation of the transmission network, regionalisation of energy production, and investments in infrastructure favouring innovative solutions.

2) Increase in security of supplies

- Diversification of supply sources by completing strategic infrastructure investment projects (LNG Terminal in Świnoujście, Baltic Pipe gas pipeline, Odessa - Brody - Płock - Gdańsk oil pipeline, restarting projects establishing a pipeline connection with Norway, construction and expansion of interconnectors at borders with Germany, the Czech Republic, Slovakia, and Lithuania).

- Diversification of energy sources in the energy mix to provide increased jobs and more opportunities for power production.

- Use of raw fuels produced in Poland (i.e., coal) as a step toward independence of power production.

- Participation in the EU internal energy market.

- Increase in storage capacity for fuel stocks.
- New contracts for importing LNG from around the world and increasing its production in Poland, which currently amounts to 4 billion $\mathrm{m}^{3}$ and is equal to $25 \%$ of Poland's demand.

3) Investment in production capacity development: Implementing the Polish government's ambitious plans for construction and expansion of power plants powered with coal (15 power units), gas (14 power units), and biomass (4 power units), as well as a hydropower plant and a nuclear plant.

4) Legal regulations favouring the development of fuel and energy markets based on principles of competition

- Introduction of methods for shaping electricity and heat prices based on market principles.

- Removing limitations related to changing power and gas suppliers.

- Removing legal limitations for investment projects, e.g., identifying shale gas deposits.

5) Improving coal mining industry management at the national level: Restructuring of unprofitable mines, change in work systems and privileges, disintermediation in the raw fuel trade, decrease in taxation, and increase in effectiveness.

6) International policy

- Instead of simply following EU policies, Poland with its convenient geographical location should skilfully negotiate with the EU and non-EU countries to protect its interests.

- Political negotiations should be conducted with the aim of operating at the fringes of the EU law, yet still within its limits (following the example of Germany: subsidies for hard coal mines until 2018 and subsidies for the shipyard in Rostock, while at the same time no permission for similar subsidies in other member states, e.g., Poland, no solidarity, liberal interpretation of laws, renegotiating goals or not implementing them in some Member States).

7) Competitiveness: Use of infrastructure to create an energy market free of monopolies, providing energy trade based on free-market principles.

8) Investment in research and development of new technologies: An exemplary project is the vertical wind turbine in Kodeń, whose efficiency is $50 \%$ greater than that of standard wind turbines. The turbine's small size allows for installing it on buildings. This is the first turbine of this kind in the world. The example shows that the development of new technologies will entail an extensive use of renewable energy sources.

9) Promoting innovative and clean coal technologies: Use and promotion of raw fuels based on their energy efficiency and cost effectiveness.

Poland needs to be in agreement on energy strategy, which would function over the years and would not change with the change of government. This would allow for better use of all favourable internal conditions existing in Poland and for a rational use of resources to ensure economic growth of the country. In the nearest 
future, the biggest difficulty for countries whose power industry is based on coal will be the additional costs related to $\mathrm{CO}_{2}$ emission permits, which will certainly decrease the competitiveness of their economies. However, Poland is in a good position with regard to the achievement of goals for the year 2020, as the country will surely be able to reach $15 \%$ of renewable energy source share in the energy mix (in 2015, it amounted to $11.5 \%$ ). Also, Poland, together with other Central European countries, is among the leaders when it comes to lowering emissions of greenhouse gasses. As for $\mathrm{CO}_{2}$ emissions, a considerable improvement is visible, unlike in several other EU countries where these emissions have increased drastically. As numerous member states have considerable problems in reaching the established goals and some of these goals are not pursued at all by the majority of EU countries (e.g., 10\% share of biofuel in the energy mix), the EU will certainly introduce changes to its 2030 climate and power policy. The changes will undoubtedly focus on increasing the economic growth and competitiveness of the EU in order to address the economic crisis we are currently witnessing, which was partially caused by climate policy.

\section{Conflict of Interest}

The authors declare no conflict of interest.

\section{References}

1. ALP E.A. Energy Consumption and Economic Growth in OECD Countries. International Journal of Energy Economics and Policy, 6 (4), 753, 2016.

2. ANNEX to Resolution of the Council of Ministers no. 202/2009 of 10 November 2009. Energy Strategy for Poland by the Year 2030. Ministry of Economy, Warsaw, 2009.

3. ARE. Statistics of the Polish Power Industry 2013. Warsaw, 2014

4. BALMACEDA M. The Politics of Energy Dependency. University of Toronto Press. London, 2013.

5. BIOENERGY FOR THE REGION - Research and Innovation Center. Available online: http://www. bioenergiadlaregionu.eu/ (date of access: 03.02.2018).

6. CENTRAL STATISTICAL OFFICE OF POLAND. Available online: http://stat.gov.pl/ (date of access: 15.01.2018).

7. CENTRE FOR POLITICAL ANALYSES OF THE UNIVERSITY OF WARSAW, Available online: http:// oapuw.pl/ (accessed on 27.12.2017).

8. CHEN L., HE F., WANG J. Allocative Efficiency of Carbon Emission Allowances among Sectors in China. Polish Journal of Environmental Studies, 27 (2), 2018.

9. DEUTCH J.M. The Crisis in Energy Policy. Harvard University Press: Cambridge, Massachusetts. London, p. 46, 2011.

10. DIRECTIVE 2010/75/EU of the European Parliament and of the Council of 24 November 2010 on industrial emissions (integrated pollution prevention and control) (IED Directive), 2010.
11. ENERDATA, GLOBAL ENERGY STATISTICAL YEARBOOK 2017. Available online: https://yearbook. enerdata.net/ (accessed on 14.02.2018).

12. ENERGY REGULATORY OFFICE, Available online: http://www.ure.gov.pl/ (accessed on 27.12.2017).

13. EUROPEAN COMMISSION. European Energy and Transport Trends to 2030 - update 2009, Brussels, August 2010.

14. EUROPEAN UNION ENERGY POLICY, European Economic Congress, Available online: www.eecpoland.eu (accessed on 14.09.2017).

15. FLEKIEWICZ M.. Use of DME as fuel for motor cars. Clean Energy, 1, 20, 2011.

16. GLACHANT J.M., LEVEQUE F., BARQUIN J., HOLZ F., NUTTALL W. Security of energy supply in Europe Natural Gas, Nuclear and Hydrogen. Loyola de Palacio series on European Energy Policy, 2014.

17. INTERNATIONAL AGENCY ENERGY, Available online: http://www.iea.org/publications/ (accessed on 27.01.2018)

18. JAWORSKI A. Methane from mines - hazard transformed into resource. Diary Newspaper Legal, 30 June, H4, 2011.

19. MENEGAKI A.N., OZTURK I. Growth and energy nexus in Europe revisited: Evidence from a fixed effects political economy model. Energy Policy, 61 (10), 881, 2013.

20. MICIUŁA I., MICIUŁA K., Renewable energy and its financial aspects as an element of sustainable development of Poland. Scientific Works of the University of Economics in Wroclaw No. 330, 239, 2014.

21. OETTINGER G. UE Proposes Tough Energy Efficiency Package. News from Business Green. March 2011.

22. PALARSKI J. Coal gassification. Ecomanager, 5, 22, 2010.

23. POLISH CHAMBER OF CHEMICAL INDUSTRY. $\mathrm{CO}_{2}$ Emission Reduction - Common Destination, Various Paths. Available online: www.pipc.org.pl (accessed on: 20.08.2017).

24. RANCI P., CERVIGNI G. The Economics of electricity markets. Theory and Policy. Loyola de Palacio series on European Energy Policy, 2014.

25. REPORT BY THE MINISTRY OF ECONOMY. Predicted demand for fuel and energy by the year 2030. Warsaw, November 2009.

26. SIMKINS B., SIMKINS R. Energy Finance and Economics - Analysis and Valuation, Risk Management and the Future of Energy. The Robert W. Kolb Series in Finance. Wiley. New Jersey, 2013.

27. STATISTICAL REVIEW OF WORLD ENERGY. Available online: https://www.bp.com/en/global/corporate/ energy-economics/statistical-review-of-world-energy.html (accessed on: 20.02.2018).

28. STEFAN-HNYDIUK A., BARTNIK P. Economic analysis of LCOE calculated for various generation technologies. Energetics, 257, 2016.

29. STĘPIEŃ P., MICIUŁA I. Liberalization of the Polish energy market and the EU commitments. Czech Journal of Social Sciences. Business and Economics 5 (2), 25, 2016.

30. THE CHANCELLERY OF THE PRIME MINISTER. Strategic Analysis Department. Model of Optimum Energy Mix for Poland by the year 2060. Warsaw, 2013.

31. VERBONG G., LOORBACH D. Governing The Energy Transition - reality, illusion or necessity? Routledge Taylor \& Francis Group. London and New York, 2012.

32. WENGER A., ORTTUNG R., PEROVIC J. Energy and the transformation of international relations, Towards a New Producer - Consumer Framework. Oxford University Press for Oxford Institute for Energy Studies, 2009. 